\title{
Effects of Trinexapac-Ethyl on different wheat varieties under desert conditions of Mexico
}

\author{
Raúl Leonel Grijalva-Contreras ${ }^{{ }^{*}}$, Rubén Macías-Duarte ${ }^{1}$, Gerardo Martínez-Díaz ${ }^{1}$, \\ Fabián Robles-Contreras ${ }^{1}$, Fidel Nuñez-Ramírez ${ }^{2}$ \\ ${ }^{1}$ National Research Institute for Forestry, Agricultural and Livestock (INIFAP), Caborca, México; \\ ${ }^{*}$ Corresponding Author: rgrijalva59mx@,hotmail.com \\ ${ }^{2}$ Agricultural Science Institute, University Autonoma of Baja California (ICA-UABC), Baja, México
}

Received 4 May 2012; revised 16 June 2012; accepted 15 July 2012

\begin{abstract}
A field study was conducted to determine the effect of Trinexapac-Ethyl (TE) on four wheat varieties (Rafi C97, Altar C84, Nacori C97 and Rayon F86) at three growth stages (first node, second node and flag leaf). TE application (150 g a.i. $h^{-1}$ ) reduced plant height and decreased grain yield at any growth stage. Yield decrease was associated to a significant reduction in the number of grains per spike and in grain weight. TE delayed flowering time and grain maturity, while stem diameter and spikes $\cdot \mathrm{m}^{-2}$ were not affected. Further studies are needed to clarify the effect of TE on wheat under desert conditions of Mexico.
\end{abstract}

Keywords: Growth Regulators; Moddus; Yield; Plant Height; Lodging

\section{INTRODUCTION}

Wheat is annually grown in 825.1 thousand hectares in Mexico, with a production of 4.14 million tones [1]. Profitability of this crop depends of yield, production cost and grain price. To obtain high yields it is necessary the use of new varieties resistant to pests and diseases, proper sowing date, good water management practices and proper nitrogen fertilization. However, yield may be affected by other factors such as frost damage and lodging [2].

Lodging in wheat is a serious problem under soils with high fertility $\left(>300 \mathrm{~kg} \cdot \mathrm{N} \cdot \mathrm{ha}^{-1}\right)$, irrigated condition and high planting density $[3,4]$. Lodging can result in yield reduction up to $50 \%$, reduced kernel weight, increase the $\mathrm{N}$ (protein) content of the grain, and reduce the milling quality [5-7].

Proper variety selection and use of growth regulators may reduce lodging in wheat [4]. Major types of growth regulators used to reduce this problem have been Cycocel (Chloromequat chloride), Ethrel (Ethephon), Apogee (Prohexadione-Ca) and Moddus (Trinexapac-ethyl) [8].

Trinexapac-ethyl (TE) belongs to cyclohexandione group and inhibits gibberellins biosynthesis $[9,10]$. TE prevents lodging not only by reducing the crop height, but also by strengthening the stem and crown root structures. In comparison to other growth retardants it is effective to increase yield grain and reduce plant height [7,11-18]. TE has other effects on wheat as increasing number of grains per spike, weight of 1000 grains, ear length and stem diameter $[15,17]$. TE applications can delay grain maturity [7] but have little effect on photo-synthesis activity, root growth and development [19] and protein content in grain [17].

The objective of this experiment was to determine the effects of TE on the grain yield, growth traits, yield components and grain quality applied in different growth stages of four winter wheat varieties grown under desert conditions of Mexico.

\section{MATERIALS AND METHODS}

\subsection{Site and Wheat Management}

The experiment was carried out in an Experimental Station of the National Research Institute for Forestry, Agricultural and Livestock (INIFAP) in Mexico (Latitude $30^{\circ} 42^{\prime} 55^{\prime \prime} \mathrm{N}$, Longitude $112^{\circ} 21^{\prime} 28^{\prime \prime} \mathrm{W}$ and altitude $200 \mathrm{~m}$ ) during 2005-2006. The soil was sandy loam with $\mathrm{pH} 7.96$ and electrical conductivity of $1.22 \mathrm{dSm}^{-1}$. Wheat varieties were sown on December 15, 2005 at $150 \mathrm{~kg} \cdot \mathrm{ha}^{-1}$. Size of experimental plot was of $5.0 \mathrm{~m} \times 6.0 \mathrm{~m}\left(30.0 \mathrm{~m}^{2}\right)$. Sowing was done using furrow $(1.0 \mathrm{~m})$ distance with two rows for each furrow spacing of $0.35 \mathrm{~m}$. Water was applied with drip irrigation and the rate of fertilization was 220-60-00 $\mathrm{kg} \cdot \mathrm{NPK} \cdot \mathrm{ha}^{-1}$, applying $60 \mathrm{~kg} \cdot \mathrm{ha}^{-1}$ of $\mathrm{N}$ and $\mathrm{P}$ at sowing time. The remaining $\mathrm{N}$ was applied through the irrigation system during crop development. Other agricultural practices (weeds, pests and diseases control) were 
applied according to recommendations for this crop in this agricultural area [2].

\subsection{TE Applications and Varieties}

TE was applied at the dose of $150 \mathrm{~g}$ a.i. $\mathrm{ha}^{-1}$ on four wheat varieties: Rafi C97, Altar C84, Nacori C97 and Rayon F89. The characteristics of wheat varieties are described in Table 1 [2]. TE was applied at three growth stages: First node, second node and flag leaf just visible 31, 32 and 37 according a Zadocks scale [20] and there was a check. Applications were made with a gasoline powered mist blower.

\subsection{Measured Variables}

Ten plants prior to harvest were randomly taken from the middle row of each plot to measure plant height, stem diameter, number of grains per spike and weight of 1000 grains. The number of spikes $\cdot \mathrm{m}^{-2}$ was determined taking two samples in each plot. Plant lodging was measured in plot center using a lodging scale from 0 to 5 , where 0 was wheat standing upright and 5 was wheat totally flat. Grain yield was obtained for the plot area and then converted to $\mathrm{kg} \cdot \mathrm{ha}^{-1}$.

\subsection{Statistical Analysis}

Analysis of variance was done considering a split plot design with three replications. The varieties were placed in the main plots and TE applications in sub plots. Means were separated with the least significant difference test (LSD) at 0.05 probability level.

\section{RESULTS AND DISCUSSION}

\subsection{Grain Yield}

$\mathrm{TE}$ at $150 \mathrm{~g}$ a.i. ha ${ }^{-1}$ decreased grain yield in the four wheat varieties at any growth stage. Grain yield reduction was $9.1 \%, 13.3 \%$ and $10.1 \%$ when TE was applied at first node, second node and flag leaf, respectively, with respect to the control. Altar C84 was less affected by TE application than Rafi C97 which had a yield reduction of 18.2\% (Table 2).

Results from this work disagree to other researchers who report a grain yield increase when TE was applied at different rates and different growth stages in wheat [7, 11-18]. An increase of $40 \%$ to $50 \%$ in grain yield was reported when TE was applied in wheat [11]. Few studies have reported a decrease of grain yield in wheat due to TE. Other studies obtained significant yield loss on Dollinco wheat variety when TE was applied a low rates (75 g a.i. ha ${ }^{-1}$ ), showing that TE was phytotoxic to wheat due to high temperatures $\left(23^{\circ} \mathrm{C}\right)$ [16]. Similar injuries were reported by other researchers [7,21] when TE was applied in early stages of wheat development and at higher rates $\left(>125 \mathrm{~g}\right.$ a.i. ha $\left.{ }^{-1}\right)$. In this work $150 \mathrm{~g} \mathrm{a.i.} \mathrm{ha}^{-1}$ was applied which might explain the reduction in grain yield. In addition, temperatures in the dessert are higher than in temperate zones. Both factors might have caused phytotoxicity of Trinexapac-ethyl to wheat. In a previous experiment conducted in Caborca, Sonora, Mexico TE was applied at $0.6 \mathrm{~g}$ a.i. $\mathrm{ha}^{-1}$ in two stages of wheat development and no damage to wheat was found [2]. This finding supports the idea that in the actual experiment the rate of the $150 \mathrm{~g}$ a.i. $\mathrm{ha}^{-1}$ becomes dangerous to wheat.

\subsection{Growth Traits}

TE had a significant effect on plant height reduction according to the stage at which it was applied. At second node the treatment had the highest plant height reduction (26.1\%), while at first node and flag leaf plant height reduction was $21.1 \%$ and $6.1 \%$, respectively; this response was similar among wheat varieties (Table 2). Stem diameter was not affected by TE application but by the variety. Rafi C97 had the highest stem diameter (3.85 $\mathrm{mm}$ ) although it was statistically similar to Nacori C97 (3.72 mm). Rafi C97 also had the lowest plant height $(78.0 \mathrm{~cm})$ (Table 2). Stem diameter and plant height are traits genetically controlled. Lodging was observed only in Rayon F89 in the untreated plots. Plants in that plots had the highest plant height and lower stem diameter, morphological traits associated with lodging problems [22,23].

A decrease of plant height from $5 \%$ to $27 \%$ due to TE has been reported [7,11-18], values that are similar to this study. According to other researchers [7,11] the greatest response was obtained when TE was applied at the second node. Other studies indicated that early TE applica-

Table 1. Genetic and phenological characteristics of the four wheat varieties.

\begin{tabular}{cccccc}
\hline Variety & Type & Grain color & Flowering (days) & Maturity (days) & Plant height (cm) \\
\hline Rafi C97 & Durum & Amber & $99-105$ & $135-147$ & $83-91$ \\
Altar C84 & Durum & Amber & $99-111$ & $135-144$ & $84-97$ \\
Nacori C97 & Durum & Amber & $96-112$ & $135-147$ & $88-98$ \\
Rayon F89 & Bread & Red & $98-105$ & $131-144$ & $88-102$ \\
\hline
\end{tabular}


Table 2. Effect of TE applied in different growth stages on grain yield, plant height and stem diameter in four wheat varieties.

\begin{tabular}{|c|c|c|c|c|}
\hline Factor & Treatments & Grain yield $\left(\mathrm{kg} \cdot \mathrm{ha}^{-1}\right)$ & Plant height $(\mathrm{cm})$ & Stem diameter $(\mathrm{mm})$ \\
\hline \multirow[t]{5}{*}{ Variety (V) } & $\mathrm{V}_{0}=$ Rafi C97 & $6749 a$ & $78.0 \mathrm{~b}$ & $3.85 \mathrm{a}$ \\
\hline & $\mathrm{V}_{1}=$ Altar C84 & $5046 \mathrm{~b}$ & $86.2 \mathrm{a}$ & $3.54 \mathrm{~b}$ \\
\hline & $\mathrm{V}_{2}=$ Nacori $\mathrm{C} 97$ & $5768 \mathrm{~b}$ & $84.6 \mathrm{a}$ & $3.72 \mathrm{ab}$ \\
\hline & $\mathrm{V}_{3}=$ Rayon F86 & $5123 \mathrm{c}$ & $84.5 \mathrm{a}$ & $3.54 \mathrm{~b}$ \\
\hline & Significance & ** & ** & $* *$ \\
\hline \multirow[t]{5}{*}{ Growth stage (S) } & $\mathrm{S}_{0}=$ Control & $6445 \mathrm{a}$ & $97.1 \mathrm{a}$ & 3.63 \\
\hline & $\mathrm{S}_{1}=$ First node & $5859 \mathrm{~b}$ & $76.6 \mathrm{c}$ & 3.61 \\
\hline & $\mathrm{S}_{2}=$ Second node & $5586 \mathrm{~b}$ & $71.8 \mathrm{~d}$ & 3.77 \\
\hline & $\mathrm{S}_{3}=$ Flag leaf & $5795 \mathrm{~b}$ & $91.4 \mathrm{~b}$ & 3.65 \\
\hline & Significance & ** & ** & N.S. \\
\hline \multirow[t]{17}{*}{ Interaction $(\mathrm{V} \times \mathrm{S})$} & $\mathrm{V}_{0} \mathrm{~S}_{0}$ & 7818 & $91.3 \mathrm{c}$ & 3.75 \\
\hline & $\mathrm{V}_{0} \mathrm{~S}_{1}$ & 6568 & $69.7 \mathrm{~g}$ & 4.07 \\
\hline & $\mathrm{V}_{0} \mathrm{~S}_{2}$ & 6103 & $67.7 \mathrm{~g}$ & 3.95 \\
\hline & $\mathrm{V}_{0} \mathrm{~S}_{3}$ & 6508 & $83.3 \mathrm{~d}$ & 3.66 \\
\hline & $\mathrm{V}_{1} \mathrm{~S}_{0}$ & 6202 & $97.3 \mathrm{~b}$ & 3.81 \\
\hline & $\mathrm{V}_{1} \mathrm{~S}_{1}$ & 5805 & $78.3 \mathrm{e}$ & 3.16 \\
\hline & $\mathrm{V}_{1} \mathrm{~S}_{2}$ & 5945 & $74.3 \mathrm{ef}$ & 3.65 \\
\hline & $\mathrm{V}_{1} \mathrm{~S}_{3}$ & 6232 & $94.6 \mathrm{bc}$ & 3.53 \\
\hline & $\mathrm{V}_{2} \mathrm{~S}_{0}$ & 5508 & $97.6 \mathrm{ab}$ & 3.53 \\
\hline & $\mathrm{V}_{2} \mathrm{~S}_{1}$ & 5130 & $75.3 \mathrm{e}$ & 3.58 \\
\hline & $\mathrm{V}_{2} \mathrm{~S}_{2}$ & 4798 & $74.3 \mathrm{ef}$ & 4.03 \\
\hline & $\mathrm{V}_{2} \mathrm{~S}_{3}$ & 5057 & $91.0 \mathrm{c}$ & 3.76 \\
\hline & $\mathrm{V}_{3} \mathrm{~S}_{0}$ & 6252 & $102.0 \mathrm{a}$ & 3.43 \\
\hline & $\mathrm{V}_{3} \mathrm{~S}_{1}$ & 5937 & $83.0 \mathrm{~d}$ & 3.63 \\
\hline & $\mathrm{V}_{3} \mathrm{~S}_{2}$ & 5500 & $71.0 \mathrm{fg}$ & 3.45 \\
\hline & $\mathrm{V}_{3} \mathrm{~S}_{3}$ & 5387 & $96.7 \mathrm{~b}$ & 3.65 \\
\hline & Significance & N.S. & $* *$ & N.S. \\
\hline
\end{tabular}

Means followed by the same letter in a column do not differ significantly (LSD 0.05); ${ }^{* *}$ Significant at 0.01 probability level; N.S. $=$ Non-significant.

tions decreased internodes length, while late applications shortened the peduncle of the plant [12]. TE has increased stem diameter of wheat $[14,16]$ results that contrast to this experiment. The absence lodging was also reported by other studies $[12,17]$. In this experiment no lodging might be due to the absence of rain and strong winds during the crop development and due to an adequate water management through drip irrigation.

TE delayed the time flowering ( 2 - 5 days) and grain maturity (4 - 7 days) with respect to untreated plots (data not shown). Similar results were reported in other experiment [7].

\subsection{Yield Components}

TE did not affect the number of spikes $\cdot \mathrm{m}^{-2}$. In contrast, there were differences among varieties for spikes $\cdot \mathrm{m}^{-2}$ (Table 3). Rayon F86 had the highest number of spikes. $\mathrm{m}^{-2}$ (496.2), followed by Rafi C97 (423.2), Nacori C97 and Altar C84, with 358.2 and 359.7 spikes $\cdot \mathrm{m}^{-2}$, respectively. TE decreased the number of grains per spike at 
Table 3. Effect of TE applied in different growth stages on spikes per $\mathrm{m}^{2}$, grains per spike and weight of 1000 grains in four wheat varieties.

\begin{tabular}{|c|c|c|c|c|}
\hline Factor & Treatments & Number spikes $\left(\mathrm{m}^{-2}\right)$ & Grains per spike & Weight of 1000 grains $(\mathrm{g})$ \\
\hline \multirow[t]{5}{*}{ Variety (V) } & $\mathrm{V}_{0}=$ Rafi C97 & $423.2 \mathrm{~b}$ & $66.1 \mathrm{a}$ & $48.7 \mathrm{c}$ \\
\hline & $\mathrm{V}_{1}=$ Altar C84 & $359.7 \mathrm{c}$ & $69.6 \mathrm{~b}$ & $51.1 \mathrm{~b}$ \\
\hline & $\mathrm{V}_{2}=$ Nacori $\mathrm{C} 97$ & $358.2 \mathrm{c}$ & $59.1 \mathrm{c}$ & $54.4 \mathrm{a}$ \\
\hline & $\mathrm{V}_{3}=$ Rayon F86 & $496.2 \mathrm{a}$ & $61.6 \mathrm{c}$ & $40.8 \mathrm{~d}$ \\
\hline & Significance & $* *$ & $* *$ & ** \\
\hline \multirow[t]{5}{*}{ Growth stage (S) } & $\mathrm{S}_{0}=$ Control & 412.2 & $74.6 \mathrm{a}$ & $51.3 \mathrm{a}$ \\
\hline & $\mathrm{S}_{1}=$ First node & 399.0 & $61.0 \mathrm{c}$ & $48.7 \mathrm{~b}$ \\
\hline & $\mathrm{S}_{2}=$ Second node & 424.6 & $54.0 \mathrm{~d}$ & $47.5 \mathrm{c}$ \\
\hline & $\mathrm{S}_{3}=$ Flag leaf & 401.3 & $66.8 \mathrm{~b}$ & $47.4 \mathrm{c}$ \\
\hline & Significance & N.S. & ** & ** \\
\hline \multirow[t]{17}{*}{ Interaction $(\mathrm{V} \times \mathrm{S})$} & $\mathrm{V}_{0} \mathrm{~S}_{0}$ & 394.6 & $83.2 \mathrm{a}$ & $51.4 \mathrm{de}$ \\
\hline & $\mathrm{V}_{0} \mathrm{~S}_{1}$ & 428.6 & $65.4 \mathrm{bcd}$ & $48.2 \mathrm{~g}$ \\
\hline & $\mathrm{V}_{0} \mathrm{~S}_{2}$ & 458.0 & $45.9 \mathrm{~h}$ & $48.8 \mathrm{fg}$ \\
\hline & $\mathrm{V}_{0} \mathrm{~S}_{3}$ & 411.3 & $70.0 \mathrm{~b}$ & $46.5 \mathrm{~h}$ \\
\hline & $\mathrm{V}_{1} \mathrm{~S}_{0}$ & 394.6 & $79.4 \mathrm{a}$ & $53.0 \mathrm{bcd}$ \\
\hline & $\mathrm{V}_{1} \mathrm{~S}_{1}$ & 337.3 & $70.2 \mathrm{~b}$ & $49.3 \mathrm{fg}$ \\
\hline & $\mathrm{V}_{1} \mathrm{~S}_{2}$ & 353.3 & $59.6 \mathrm{def}$ & $50.4 \mathrm{ef}$ \\
\hline & $\mathrm{V}_{1} \mathrm{~S}_{3}$ & 353.3 & $69.5 \mathrm{~b}$ & $51.9 \mathrm{cde}$ \\
\hline & $\mathrm{V}_{2} \mathrm{~S}_{0}$ & 350.0 & $70.4 \mathrm{a}$ & $56.9 \mathrm{a}$ \\
\hline & $\mathrm{V}_{2} \mathrm{~S}_{1}$ & 362.0 & $53.6 \mathrm{fg}$ & $52.7 \mathrm{bcd}$ \\
\hline & $\mathrm{V}_{2} \mathrm{~S}_{2}$ & 371.3 & $51.4 \mathrm{gh}$ & $54.4 \mathrm{~b}$ \\
\hline & $\mathrm{V}_{2} \mathrm{~S}_{3}$ & 349.3 & $61.0 \mathrm{cde}$ & $53.7 \mathrm{bc}$ \\
\hline & $\mathrm{V}_{3} \mathrm{~S}_{0}$ & 509.3 & $65.4 \mathrm{bcd}$ & $43.8 \mathrm{i}$ \\
\hline & $\mathrm{V}_{3} \mathrm{~S}_{1}$ & 468.0 & $55.0 \mathrm{efg}$ & $40.0 \mathrm{j}$ \\
\hline & $\mathrm{V}_{3} \mathrm{~S}_{2}$ & 516.0 & 59.2 defg & $40.9 \mathrm{j}$ \\
\hline & $\mathrm{V}_{3} \mathrm{~S}_{3}$ & 491.3 & $67.1 \mathrm{bc}$ & $37.6 \mathrm{k}$ \\
\hline & Significance & N.S. & $* *$ & $* *$ \\
\hline
\end{tabular}

Means followed by the same letter in a column do not differ significantly (LSD 0.05); ${ }^{* *}$ Significant at 0.01 probability level; N.S. $=$ Non-significant.

any growth stage. At second node had the highest percentage of reduction $(27.6 \%)$, whereas at first node and flag leaf, percentage of reduction was $18.2 \%$ and $10.4 \%$, respectively. Rafi C97 was more sensitive to TE since its reduction was $44.8 \%$ and Rayon F86 was the least sensitive (Table 3). The 1000 grain weight decreased with TE application at any growth stage. The highest reduction on 1000 grains weight was observed when TE was applied at flag leaf and second node growth stage $(7.6 \%$ and 7.4\%). Rafi C97 and Rayon F86 were more affected by
TE applied at leaf flag stage, while Altar C84 and Nacori C97 when TE was applied at first node stage (Table 3).

TE did not affect the number of spikes $\cdot \mathrm{m}^{-2}$, which agrees to result obtained by [16] and are different to results from $[14,15]$ when they applied TE at a similar dose. In contrast, there were differences for spikes $\cdot \mathrm{m}^{-2}$ among varieties (Table 3). Grain yield reduction due to $\mathrm{TE}$ in this experiment was due to reduction number of grains in the spikes and reduction in the weight of 1000 grains, results that are opposite to $[14,17]$. The differ- 
ences in yield components among wheat varieties are due to their genetic traits as reported by other researchers [24, 25].

\section{CONCLUSION}

Trinexapac-ethyl at $150 \mathrm{~g}$ a.i. $\mathrm{ha}^{-1}$ applied at different growth stages reduced significantly plant height and decreased average grain yield in different wheat varieties. The decrease of grain yield was associated to a significant reduction in the number of grains per spike and weight of 1000 grains. Further studies are needed to clarify the effect of TE on wheat under desert conditions of Mexico.

\section{REFERENCES}

[1] Food and Agriculture Organization of the United Nations (FAO) (2009) Producción agrícola. http://faostat.fao.org//site/339/default.aspx

[2] Grijalva, C.R. and Robles, F. (2004) Tecnología para Producción de Trigo en el Noroeste de Sonora. Folleto Técnico No. 5 INIFAP-CIRNO-CECAB, 37 p.

[3] Webster, J.R. and Jackson, L.F. (1993) Management practices to reduce lodging and maximize grain yield and protein content of fall-sown irrigated hard red spring wheat. Field Crops Research, 33, 249-259. doi:10.1016/0378-4290(93)90083-Y

[4] Tripathi, S.C., Sayre, K.D. and Narang, R.S. (2004) Lodging behavior and yield potential of spring wheat (Triticum aestivum L.): Effects of ethephon and genotypes. Field Crop Research, 87, 207-220.

doi:10.1016/j.fcr.2003.11.003

[5] Pinthus, M.J. (1973) Lodging in wheat, barley and oats. The phenomenon, its causes, and preventive measures. Advances in Agronomy, 25, 209. doi:10.1016/S0065-2113(08)60782-8

[6] Pumphrey, F.V. and Rubenthaler, G.L. (1983) Lodging effects on yield and quality of soft white wheat. Cereal Chemistry, 60, 268-270.

[7] Wiersma, J.J., Beverly, R. and Camerum, J.N. (2005) Efficacy and crop safety of Trinexapac-ethyl to reduce plant height and improve straw strength in spring wheat. NCWSS Research Report.

[8] Paridaen, A. (2009) Investigating the use of plant growth regulators in New Zealand and Australia. Australian University Crops Competition News Zealand Study Tours Proyect Report, 9 p.

[9] Rademacher, W. (2000) Growth retardants: Effects on gibberellins biosynthesis and other metabolic pathways. Annual Review of Plant Physiology and Plant Molecular Biology, 51, 501-577. doi:10.1146/annurev.arplant.51.1.501

[10] Hafner, V. (2001) Moddus-universal product for lodging prevention in cereals. Proceeding of the 5th Slovenian Conference of Plant Protection, Catez ob Savi, Slovenia, 6-8 March 2001, 167-172.

[11] Lozano, C.M. and Laden, M.I. (2001) Effect of growth regulators on yield and height in two cultivars of wheat. In: Congreso Nacional de Trigo. 5 to Simposio Nacional de cereales de siembra, INTA, Argentina.

http://www.inta.gov.ar

[12] Lozano, C.M. and Laden, M.I. (2002) Respuesta del cultivar Premium 13 a la aplicación de un regulador de crecimiento solo y en mezcla con fungicida. In: Congreso Nacional de Trigo. 6 to Simposio Nacional de cereales de siembra, INTA, Argentina. http://www.inta.gov.ar

[13] Llumae, E. (2002) The influence of growth regulators Moddus $250 \mathrm{EC}$ on different cereal species. Journal of Agricultural Science, 13, 73-78.

[14] Zagonel, J., Venancio, W.S. and Kunz, R.P. (2002) Effect of growth regulators on wheat crop under different nitrogen rates and plant density. Planta Daninha, 20, 471-476. doi:10.1590/S0100-83582002000300019

[15] Zagonel, J., Venancio, W.S. and Tanamati, M. (2002) Nitrogen doses and plant densities with and without a growth regulators affecting wheat, cultivar OR-1. Ciencia Rural, Santa María, 32, 25-29.

[16] Schürch, G.C. (2006) Efecto de diferentes reguladores de crecimiento sobre la morfología y rendimiento de tres genotipos de trigo en la provincia de Bio-Bio. Tesis., Universidad Austral de Chile, $44 \mathrm{p}$.

[17] Matysiak, K. (2006). Influence of Trinexapac-ethyl on growth and development of winter wheat. Journal of Plant Protection Research, 46, 133-134.

[18] Berti, M., Zagonel, J. and Fernandez, E.C. (2007) Yield of wheat cultivars in function of Trinexapac-ethyl and nitrogen rates. Scientia Agraria, 8, 127-134.

[19] Henderson, E.J., Maurer, W., Cornes, D.W. and Ryan, P.J. (1998) Beneficial effects of the plant growth regulators CGA163'935 in oilseed rape under UK condition. The BCPC Conference-Weed, 2, 103-210.

[20] Zadocks, J., Ghang, C. and Konzak, C.F. (1974) A decimal code for the growth stage of cereals. Weed Research, 14, 415-421. doi:10.1111/j.1365-3180.1974.tb01084.x

[21] Espindula, M.C., Rocha, V.S., Grossi, J.A.S., Souza, M.A., Souza, L.T. and Favorato, L.F. (2009) Use of growth retardants in wheat. Planta Daninha, 27, 379-387. doi:10.1590/S0100-83582009000200022

[22] Crook, M.J. and Ennos, A.R. (1994) Stem and root characteristics associated with lodging resistance in four winter wheat cultivars. The Journal of Agricultural Science, 123, 167-174. doi:10.1017/S0021859600068428

[23] Zuber, V., Winzeler, H., Messmer, M., Keller, M., Keller, B., Schmid, J.D. and Stamp, P. (1999) Morphological traits associated with lodging resistance of spring wheat (Triticum aestivum L.). Journal Agronomy Crop Science, 182, 17-24. doi:10.1046/j.1439-037x.1999.00251.x

[24] Hussain, S., Amir, S., Hussain, M.I. and Saleem, M. (2001) Growth and yield response on three wheat varieties to different seedling density. International Journal of Agriculture and Biology, 3, 228-229.

[25] Musaddique, M., Hussain, A., Wajid, S.A. and Ahmad, A. (2000) Growth, yield and components of yield of different genotypes of wheat. International Journal of Agriculture and Biology, 2, 242-244. 